\title{
Antidiarrhoeal and antioxidant properties of ethanol leaf extract of Pseudocedrela kotschyi
}

\author{
Grace Akanimo Essiet ${ }^{1}$, Akuodor Godwin Christian ${ }^{2 *}$, Aja Daniel Ogbonna ${ }^{2}$, Megwas Anthony Uchenna $^{3}$, Ekenjoku \\ John Azubuike ${ }^{4}$, Nworie Emmanuel Michael ${ }^{4}$ \\ ${ }^{1}$ Department of Pharmacology, College of Medical Sciences, University of Calabar, Nigeria. ${ }^{2}$ Department of Pharmacology and Therapeutics, Faculty of \\ Medicine, Ebonyi State University, Abakaliki, Nigeria. ${ }^{3}$ Department of Optometry, School of Health, Federal University of Technology, Owerri, Nigeria. \\ ${ }^{4}$ Department of Pharmacology and Therapeutics, College of Health Sciences, Abia State University, Uturu, Nigeria.
}

\begin{tabular}{l} 
ARTICLE INFO \\
\hline Article history: \\
Received on: $13 / 11 / 2015$ \\
Revised on: 22/12/2015 \\
Accepted on: 09/01/2016 \\
Available online: $30 / 03 / 2016$ \\
\hline Key words: \\
Antidiarrhoeal; Antioxidant; \\
Pseudocedrela kotschyi; Leaf \\
extract; Rats.
\end{tabular}

\begin{abstract}
This study was carried out to establish the antidiarrhoeal and antioxidant properties of the ethanol leaf extract of Pseudocedrela kotschyi in wistar albino rats. The effect of the ethanol extract on castor oil induced diarrhoea, motility of the GIT using the charcoal plug method and castor oil induced intestinal fluid accumulation in rats were evaluated. The antioxidant potential of the leaf extract was investigated by measuring its capability for scavenging 2, 2-diphenyl-1-picrylhydrazyl (DPPH) radical. The phytochemical constituents and the oral acute toxicity of ethanol leaf extract were also determined in rats. Generally, the ethanol leaf extract at all doses used, was found to posses significant $(\mathrm{P}<0.05)$ concentration dependent antidiarrhoeal, antimotility and antienteropooling activity. The leaf extract also exhibited strong antioxidant activity. The phytochemical studies revealed the presence of alkaloids, tannin, cardiac glycosides, steroids, flavoniods and saponins. The $\mathrm{LD}_{50}$ in rats was above $5000 \mathrm{mg} / \mathrm{kg}$. The ethanol leaf extract of Pseudocedrela kotschyi has demonstrated strong antidiarrhoeal, antimotility, antienteropooling and antioxidant activities, supporting previous claims of its traditional use in the treatment of different diseases.
\end{abstract}

\section{INTRODUCTION}

Diarrhoeal diseases account for over 5-8 million deaths globally, each year in children less than 5 years in developing countries (WHO, 2006; Moszynski, 2007; Khalilur et al., 2015). The incidence of diarrhoeal disease remains high despite the efforts of various governments and international organizations to prevent it. Thus it becomes imperative to identify and investigate available natural products as alternative to currently used antidiarrhoeal agents, which are not free from adverse effects (Akuodor et al., 2014). Medicinal plants have been the most accessible form of therapy for the less privileged in the global population (Espinosa et al., 2012). This has been the justification for the push of the World Health Organization (WHO) for scientific validation of ethnobotanical knowledge of medicinal plants (Ministério da Saúde, 2005). Pseudocedrela kotschyi Schweint. Harms, is a plant that belongs to the family Meliaceae.

\footnotetext{
* Corresponding Author

Godwin Christian Akuodor, Department of Pharmacology and

Therapeutics, Faculty of Medicine, Ebonyi State University, Abakaliki,

Nigeria. Email:goddyakuodor[at]yahoo.com
}

P. kotschyi grows well on moisture of heavy soils. The decoction of the leaf is used traditionally in the folk medicine in Nigeria for the treatment of a number of diseases and health conditions, including malaria, fever, pains, diabetes and convulsion (Akuodor et al., 2015; Akuodor et al., 2013; Georgewill and Georgewill, 2009; Anuka et al.,1999). The interest in this plant was justified by its potential medicinal value against diseases. Therefore, the aim of this study was to investigate the antidiarrhoeal and antioxidant effects of ethanol leaf extract of $P$. kotschyi.

\section{MATERIALS AND METHODS}

\section{Plant collection}

The leaves of Pseudocedrela kotschyi were collected from Chaza, Niger State, Nigeria. The plant was identified by a taxonomist in the Department of Medicinal plant Research and Traditional Medicine, National Institute for Pharmaceutical Research \& Development (NIPRD), Abuja, Nigeria where voucher specimens were deposited with the number, NIPRD/H/6542. The international plant name index is Meliaceae Pseudocedrela kotschyi-Bot. Jahrb. Syst.22 (1): 154. 1895 (19 Nov. 1895) (IK). 


\section{Sample extraction}

Three hundred and fifty grams $(350 \mathrm{~g})$ of the powdered leaves were macerated overnight in $1.5 \mathrm{~L}$ of ethanol. The mixture was filtered and dried on a water bath at reduced temperature of $45^{\circ} \mathrm{C}$ and the residues obtained were weighed and stored at $4^{\circ} \mathrm{C}$.

\section{Phytochemical screening}

Phytocchemical analysis of the ethanol leaf extract was carried out employing standard procedures (Harborne, 1992; Evans, 2005).

\section{Animals}

Adult wistar rats (200-250 g) of both sexes obtained from Animal House of Department of Anatomy, Ebonyi State University, Abakaliki, were used for the study. The rats were housed in cages at room temperature and moisture, under naturally illuminated environmental of 12:12 $\mathrm{h}$ dark/ light cycle. The animals were fed on standard feed and water ad libatum. A standard protocol was drawn in accordance with the Good laboratory Practice (GLP) regulation [ENV/MC/CHEM (98)] (1997). The National Institute of Health Guide for the care and use of Laboratory Animals was adopted for the animal protocol in this study (NIH, 1978).

\section{Acute toxicity test}

The $\mathrm{LD}_{50}$ of the leaf extract was examined to determine the safety of the agent in rats, in vivo following OECD (2010) method. Dose levels used ranged from $10-5000 \mathrm{mg} / \mathrm{kg}$. The rats were observed for signs of toxicity such as salivation, stretching of the body, weakness, paw licking respiratory distress, coma and death for $24 \mathrm{~h}$ and $72 \mathrm{~h}$ respectively.

\section{Antidiarrhoeal evaluation}

\section{Castor oil induced diarrhoea}

Wistar albino rats for this test were first observed for any wet faeces. The droppings were easily distinguished from the normal dry faeces which were regular in shape, hard and did not stain the white transparent paper. Rats that produced wet faeces were not used for the study. The ethanol leaf extract of Pseudocedrela kotschyi (100, 200 and $400 \mathrm{mg} / \mathrm{kg}), 20 \mathrm{ml} / \mathrm{kg}$ normal saline (negative control) or $4 \mathrm{mg} / \mathrm{kg}$ loperamide (positive control) were orally administered $60 \mathrm{~min}$ before diarrhoea induction. Diarrhoea was induced by oral administration of $1 \mathrm{ml}$ castor oil to $24 \mathrm{~h}$ fasted rats. The rats in individual cages were observed for $4 \mathrm{~h}$ for the presence or absence of wet faeces. (Akuodor et al., 2010; Akuodor et al., 2012).

\section{Intestinal transit test}

The wistar albino rats used for this test were deprived of food for $24 \mathrm{~h}$ but had access to water. The rats were grouped into 5 of 6 per cage. Rats in group 1 were administered with normal saline (negative control). Group 2, 3 and 4 were administered with 100,200 and $400 \mathrm{mg} / \mathrm{kg}$ of the leaf extract, while group 5 received $5 \mathrm{mg} / \mathrm{kg}$ of atropine. After $30 \mathrm{~min}$, the animals were orally dosed with $1 \mathrm{ml}$ of freshly prepared charcoal meal (10\% in tragacanth). The rats were sacrificed $30 \mathrm{~min}$ later and gastrointestinal tract removed. The distance travelled by the marker (charcoal meal) from the pylorus to caecum was measured and expressed as the percentage of the total length of the small intestine (Abere et al., 2010; Akuodor et al., 2014).

\section{Intestinal fluid accumulation}

The rats used for this test were starved for $24 \mathrm{~h}$ prior to the study but allowed access to water. The rats were grouped into 5 of 6 per cage. Rats in group 1 were administered with normal saline (negative control). Group 2, 3 and 4 were administered with 100,200 and $400 \mathrm{mg} / \mathrm{kg}$ of the leaf extract, while group 5 received $4 \mathrm{mg} / \mathrm{kg}$ of loperamide respectively. After $30 \mathrm{~min}$, each rat was orally challenged with $1 \mathrm{ml}$ of castor oil. They were sacrificed (30 min after) and the whole stomach contents were milked into a measuring cylinder and the volume measured (Mujumdar et al., 2005).

\section{DPPH radical scavenging activity}

DPPH radical scavenging activity of the ethanol leaf extract of Pseudocedrela kotschyi was determined according to the method described by Kaneria et al. (2012) with slight modification. The stock solution of the extract was diluted to final concentrations of $250,200,150,100$ and $50 \mu \mathrm{g} / \mathrm{mL}$ in methanol. 1 $\mathrm{mL}$ of a $0.3 \mathrm{mM}$ DPPH methanol solution was added to $2.5 \mathrm{~mL}$ solution of the extract and was allowed to react at room temperature for $30 \mathrm{~min}$ under complete dark. The absorbance of the resulting mixture after the reaction was taken at $517 \mathrm{~nm}$ using UV visible spectrophotometer.

\section{Statistical Analysis.}

The results are presented as mean \pm standard error of mean (SEM). The one-way ANOVA test was used to analyze and compare the data, while $\mathrm{p}<0.05$ was considered as statistically significant.

\section{RESULTS}

\section{Phytochemical screening of $P$. kotschyi}

Phytochemical screening of the crude extract of $P$. kotschyi revealed the presence of alkaloids, flavonoids, terpenoids, tannins, saponins, steroids, glycosides and reducing sugar.

\section{Acute toxicity test}

The ethanol leaf extract of $P$. kotschyi did not produce any mortality up to the oral dose of $5000 \mathrm{mg} / \mathrm{kg}$ in rats, thus the $\mathrm{LD}_{50}$ was indeterminable. There were no significance changes in behaviour, mood and motor activity.

\section{Effect of castor Oil-Induced Diarrhoea}

In castor oil induced diarrhoeal test, the ethanol leaf extract of $P$. kotschyi showed a marked antidiarrhoeal effect in the rats (Table 1). In both doses used (100, $200400 \mathrm{mg} / \mathrm{kg}$ ), the extract produced significant $(\mathrm{p}<0.05)$ decrease defecation in 
rats. The result is comparable to the effect produced by the standard antidiarrhoeal drug, loperamide $(4 \mathrm{mg} / \mathrm{kg})$.

Table 1: Effect of ethanol leaf extract of Pseudocedrela kotschyi on castor oilinduced diarrhoea in rats.

\begin{tabular}{lccc}
\hline \multicolumn{1}{c}{ Drug } & Dose $(\mathbf{m g} / \mathbf{k g})$ & $\begin{array}{c}\text { Mean frequency of } \\
\text { diarrhoea in } \mathbf{~ h ~}\end{array}$ & $\begin{array}{c}\text { Inhibition } \\
(\boldsymbol{\%})\end{array}$ \\
\hline Control & $20 \mathrm{ml} / \mathrm{kg}$ & $5.00 \pm 0.37$ & - \\
$P$. kotschyi & 100 & $1.67 \pm 0.33$ & $67^{*}$ \\
& 200 & $1.33 \pm 0.21$ & $73^{*}$ \\
Loperamide & 400 & $0.45 \pm 0.21$ & $91^{*}$ \\
\hline
\end{tabular}

Values were expressed as mean \pm SEM. $(n=6) . * \mathrm{p}<0.05$ when compared with control group.

\section{Effect on intestinal transit Test}

The ethanol extract of $P$. kotschyi decreased the gastrointestinal distance travelled by the charcoal meal in the rats noticeably compared with the control group. Atropine $(5 \mathrm{mg} / \mathrm{kg})$ produced a marked decrease in the propulsion of charcoal meal through gastrointestinal tract (Table 2).

Table 2: Effect of ethanol leaf extract of Pseudocedrela kotschyi on intestinal transit time in rats.

\begin{tabular}{lllll}
\hline \multicolumn{1}{c}{ Drug } & $\begin{array}{c}\text { Dose } \\
(\mathbf{m g} / \mathbf{k g})\end{array}$ & $\begin{array}{c}\text { Mean } \\
\text { intestinal } \\
\text { length }(\mathbf{c m})\end{array}$ & $\begin{array}{c}\text { Mean distance } \\
\text { travelled } \\
\text { by marker } \\
(\mathbf{c m})\end{array}$ & $\begin{array}{c}\text { Inhibition } \\
(\%)\end{array}$ \\
\hline Control & $20 \mathrm{ml} / \mathrm{kg}$ & $94.50 \pm 3.34$ & $93.67 \pm 3.53$ & - \\
$P$. kotschyi & 100 & $83.00 \pm 4.91$ & $40.33 \pm 3.37$ & $57^{*}$ \\
& 200 & $92.00 \pm 3.28$ & $36.00 \pm 4.90$ & $62^{*}$ \\
& 400 & $88.50 \pm 2.11$ & $32.83 \pm 2.09$ & $66^{*}$ \\
Atropine & 5 & $80.00 \pm 4.28$ & $30.33 \pm 2.01$ & $68^{*}$ \\
Values were expressed as mean \pm SEM. $(\mathrm{n}=6){ }^{*} \mathrm{p}<0.05$ when compared with \\
control group.
\end{tabular}

\section{Effect on castor oil induced intestinal fluid accumulation}

In this test, ethanol leaf extract of $P$. Kotschyi at both doses used $(100,200,400 \mathrm{mg} / \mathrm{kg}$ produced significant $(\mathrm{p}<0.05)$ and dose dependent reduction in intestinal fluid volume (Table $3)$.The standard drug loperamide $(4 \mathrm{mg} / \mathrm{kg})$ also significantly inhibited $(\mathrm{p}<0.05)$ the intestinal fluid accumulation.

Table 3: Effect of ethanol leaf extract of Pseudocedrela kotschyi on castor oilinduced intestinal fluid accumulation in rats.

\begin{tabular}{lccc}
\hline \multicolumn{1}{c}{ Drug } & $\begin{array}{c}\text { Dose } \\
(\mathbf{m g} / \mathbf{k g})\end{array}$ & $\begin{array}{c}\text { Mean volume of intestinal } \\
\text { contents }\end{array}$ & $\begin{array}{c}\text { Inhibition } \\
(\mathbf{\%})\end{array}$ \\
\hline Control & $0.2 \mathrm{ml}$ & $4.33 \pm 0.13$ & - \\
$P$. kotschyi & 100 & $1.40 \pm 0.15$ & $68^{*}$ \\
& 200 & $1.07 \pm 0.10$ & $75^{*}$ \\
& 400 & $0.80 \pm 0.09$ & $82^{*}$ \\
Loperamide & 4 & $0.72 \pm 0.07$ & $83^{*}$ \\
\hline
\end{tabular}

Values were expressed as mean \pm SEM. $(n=6) . * p<0.05$ when compared with
control group.

Table 4: DPPH scavenging activity of ethanol lea extract of Pseudocedrela kotschyi at different concentrations $(\mu \mathrm{g} / \mathrm{ml})$ and $\mathrm{IC}_{50}$ values.

\begin{tabular}{ccc}
\hline Conc. $\boldsymbol{\mu g} / \mathbf{m l}$ & EEPK & Standard (Ascorbic acid) \\
\hline 50 & $50.5 \pm 2.3$ & $67.4 \pm 2.1$ \\
100 & $75.9 \pm 2.6$ & $82.3 \pm 2.4$ \\
150 & $78.6 \pm 3.2$ & $87.5 \pm 2.5$ \\
200 & $81.2 \pm 3.0$ & $90.4 \pm 3.1$ \\
250 & $88.7 \pm 3.2$ & $96.5 \pm 3.3$ \\
IC $_{50}$ & $48.9 \pm 2.8$ & $3.7 \pm 1.7$ \\
\hline
\end{tabular}

Data represented as mean \pm SEM. $(\mathrm{n}=3)$. $\mathrm{E}=$ ethanol, $\mathrm{E}=$ extract, $\mathrm{P}=$ Pseudocedrela, $\mathrm{k}=$ kotschyi

\section{Effect on DPPH radical scavenging test}

The leaf extract of $P$. kotschyi at concentrations used (50$250 \mu \mathrm{g} / \mathrm{ml}$ ), showed strong DPPH free radical scavenging activity (Table 4). The result of DPPH scavenging activity in this study indicates that the plant was potentially active.

\section{DISCUSSION}

This study was conducted to establish the potential pharmacological properties of Pseudocedrela kotschyi based on its use in traditional medicine. Diarrhoea can be described as the abnormally frequent defecation due to a disturbance in the transport of water and electrolytes in the intestines. Castor oil produces diarrhoea due to its active component, ricinolic acid which increases peristaltic activity in small intestine leading to changes in the electrolyte permeability of the intestinal mucosal membrane (Akuodor et al., 2010). Several mechanisms have been proposed to explain the diarrhoeal effect of castor oil which includes inhibition of intestinal $\mathrm{Na}+\mathrm{K}+$ ATPase activity, thus decreasing normal fluid absorption, activation of adenylate cyclase or mucosal cAMP-mediated active secretion (Capasso et al., 1994; Imam et al., 2012). Castor oil is usually metabolized into ricinolic acid in the gut, and this causes irritation and inflammation in the intestinal mucosa leading to the release of prostaglandins (Khalilur et al., 2015). The released prostaglandins initiate vasodilatation, smooth muscle contraction, and mucus secretion in the small intestines. Inhibitors of prostaglandins biosynthesis delay castor oil induced diarrhoea (Akuodor et al., 2011). The leaf extract of Pseudocedrela kotschyi significantly reduced the amount of faeces in castor oil induced diarrhoea in rats at the doses used (100, 200 and $400 \mathrm{mg} / \mathrm{kg}$ ). The leaf extract exhibited comparable characteristics as the reference drug, Loperamide which at present is one the most potent and widely employed antidiarrhoeal drugs. Apart from regulating the gastrointestinal tract, Loperamide has been reported to slow down transit in the intestine, decrease colon flow rates and any effect on colonic motility (Camilleri, 2004; Akuodor et al., 2011). The antimuscarinic agent (Atropine) and different doses of the leaf extract reduced the propulsive movement of the charcoal plug dose dependently. This is possible due to its anticholinergic activity. Moreso, our results significantly demonstrated an inhibition of castor oil induced enteropooling with reduction of the volume of intraluminal contents. These results suggest that the ethanol leaf extract of $P$. kotschyi contain antidiarrheal properties. Previous report on the phytochemical screening of $P$. kotschyi leaves has shown the presence of alkaloids, tannin, cardiac glycosides, steroids, flavoniods and saponins (Akuodor et al., 2014). Plants containing these secondary metabolites have been reported to possess antidiarrhoeal activities. However, previous reports have also shown that flavonoids have ability to inhibit intestinal motility and water and electrolytes secretion (Di Carlo et al., 1993). It could therefore be suggested that the secondary metabolites present in P. kotschyi leaves are responsible for the observed biological activities.Results show that $P$. kotschyi leaf possesses potential antioxidant activity. 
Compounds such as alkaloids, flavonoids, terpenoids and vitamins which have the ability to scavenge free radicals are produced by the natural machinery of the plants (Cait et al., 2003). Ingestion of natural antioxidants through food and medicine prepared from plants can reduce the complications connected with the presence of free radicals (Veerapur et al., 2009). The results further suggest that $P$. kotschyi leaf could be used in food industry as natural antioxidant. In conclusion, the findings of the present study provide convincing evidence that ethanol leaf extract of P. kotschyi possesses remarkable antidiarrheal and antioxidant activities. The Antidiarrheal, antimotility antienteropooling effects are rapid, long lasting and statistically significant at both doses. However, further chemical studies are required to isolate the bioactive compounds and elucidate the precise mechanisms responsible for the observed pharmacological activities of this medicinal plant.

\section{Conflict of interest statement}

We declare that we have no conflict of interest.

\section{Acknowledgement}

The authors are grateful to Mr. Simon E. Nwibo and Mr. Chibueze Nwonu for their technical assistance.

\section{REFERENCES}

Abere TA, Okoto PE, Agoreyo FO. Antidiarrhoea and toxicological evaluation of the leaf extract of Dissotis rotundifolia triana (Melastomataceae), Comp. and Altern. Med., 2010; 10:71.

Akuodor GC, Idris-Usman M, Ugwu TC, Akpan JL, Irogbeyi LA, Iwuanyanwu TC, Osunkwo AU. Ethanolic leaf extract of Verbena hastate produces antidiarrhoeal and gastrointestinal motility slowing effects in albino rats. J. Med. Plants Res., 2010; 4(16): 1624-1627.

Akuodor GC, Muazzam I, Usman-Idris M, Megwas AU, Akpan JL, Chilaka KC, Okoroafor DO, Osunkwo UA. Evaluation of the antidiarrhoeal activity of methanolic leaf extract of Bombax buonopozense in rats. Ibnosina J. Med. Biomed. Sci, 2011; 3 (1):15-20.

Akuodor GC, Mbah CC, Essien AD, Akpan JL, Ezeokpo BC, Iwuanyanwu TC, Osunkwo AU. Ulcer-protective and antidiarrhoeal effects of the aqueous stem bark extract of Bridelia ferruginea in rodents. Pharmacologia, 2012; 3(11):591-597.

Akuodor GC, Essien AD, Essiet GA, David-Oku E, Akpan JL, Udoh FV. Evaluation of antipyretic potential of Pseudocedrela kotschyi Schweint. Hams (Meliaceae). European Journal of Medicinal Plants, 2013; 3(1):105-113

Akuodor GC, Ibrahim JA, Akpan JL, Okorie AU and Ezeokpo BC. Phytochemical and antidiarrhoeal properties of methanolic leaf extract of Maerua crassifolia Forssk. European Journal of Medicinal Plants, 2014; 4 (10):1223-1231.

Akuodor GC, Ajoku GA, Ezeunala MN, Chilaka KC, Asika EC. Antimalarial potential of the ethanolic leaf extract of Pseudocedrela kotschyi. Journal of Acute Disease, 2015; 4: 23-27.

Anuka JA, Ijezie DO, Ezebnik ON. Investigation of Pharmacological actions of the extract of the extract Pseudocedrela kotschyi in Laboratory animals. ABSTRACTS of the proceedings of XXVII $^{\text {th }}$ Annual Regional Conference of WASP 1999 ; PP 9-10.

Cait YZ, Sun M, Corke H. Antioxidant activity of betalains from plants of the Amaranthaceae. J Agric Food Chem. 2003;51: 2288-94.

Camilleri M. Chronic diarrhoeal: A review of pathophysiology and management for the Clinical gastroenterologist. Clin. Gastroenterol Hepatol., 2004; 2: 198.
Capasso F, Mascolo N, Izzo AA and Gaginella TS. Dissociation of castor oil-induced diarrhoea and intestinal mucosal injury in rat: effect of N(G)-nitro-L-arginine methylester, British Journal of Pharmacology, 1994; (4): 1127-1130.

Di Carlo G, Autore G, Izzo AA. Inhibition of intestinal motility and secretion by flavonoids in mice and rats: structureactivity relationships Journal of Pharmacy and Pharmacology, 1993; 45(12):1054-1059.

ENV/MC/CHEM (98) 17. OECD series on principles of good laboratory Practice and compliance monitoring number 1. OECD (as revised in 1997). Environmental Directorate, Organization for Economic Co-operation and Development Paris. 1998. www.iriphrma.com/ download/principles on- GLD.pdf.

Espinosa MM, Bieski IGC, Martins DTO. (2012). Probability sampling design in ethnobotanical surveys of medicinal plants. Rev Bras Farmacogn, 2012; 22: 1362-1367.

Evans, W. C. (Ed). (2005). Trease ans Evans Pharmacognosy $\left(15^{\text {th }}\right.$ edn). Reed Elsevier India (Pvt) Ltd: New Delhi; 174, 224-304, 411413,535 .

Georgewill UO, Georgewill OA. Effect of extract of Pseudocedrela kotschyi on blood glucose concentration of alloxan induced diabetic albino rats. Eastern Journal of Medicine 2009; 14: 17-19.

Harborne, J. B. 1992. Phytochemical methods. A guide to modern technique of plant analysis. Chapman and Hill, London, p. 279.

Imam MZ, Sultana S, and Akter S. Antinociceptive, antidiarrheal, and neuropharmacological activities of Barringtonia acutangula, Pharmaceutical Biology, 2012; 50 (9): 1078-1084.

Kaneria M, Kanani B, Chanda S. Assessment of effect of hydroalcoholic and decoction methods on extraction of antioxidants from selected Indian medicinal plants. Asian Pac J Trop Biomed 2012; 2(3): 195-202.

Khalilur R, Ashraf UC, Mohammed TI, Anisuzzaman C, Muhammad EU, and Chandra DS. Evaluation of Antidiarrheal Activity of Methanolic Extract of Maranta arundinacea Linn. Leaves. Advances in Pharmacological Sciences; 2015:1-6.

Ministério da Saúde. 2005. Produce and apply knowledge in the pursuit of universality and equity, with quality health care to the population. Department of Science, Technology and Strategic Inputs. Anais second dam. National Conference on Science, Technology and Innovation in Health. SCTIE / DECIT, CNS. Brasilia. [Translated from Portuguese].

Moszynski P. Diarrhoeal diseases still kill more than $1.5 \mathrm{~m}$ children fewer than 5 each year. BMJ 2007; 335: 1227.

Mujumdar AM, Misar AV, Upadhye. Antidiarrhoeal activity of ethanol extract of the bark of Dalbergial lanceolaria. Journal of Ethnopharmacol., 2005; 102(2):213-216.

NIH (National Institute of Health), 1978. Guide for the Care and Use of Laboratory Animals (revised). 1978. NIH Publication No. 83-23. National Institute of Health, Bethesda, MD.

OECD Guidelines for the Testing of Chemicals. Testing no. 423 Acute oral toxicity Acute Toxicity Class Method, 2010 1(4):1-14

Veerapur VP, Prabhakar KR, Parihar VP, Kandadi MR, Ramakrishana S, Mishra B, Satish R, Srinivasan KK, Priyadarsini KI, Unnikrishnan MK. Ficus racemosa stem bark extract: A potent antioxidant and a probable natural radio protector. Evid Based Compl Alter Med. 2009; 6: 317-24.

World Health Organization (WHO), Country Health System Fact Sheet, 2006.

\section{How to cite this article:}

Essiet GA, Christian AG, Ogbonna AD, Uchenna MA, Azubuike EJ, Michael NE. Antidiarrhoeal and antioxidant properties of ethanol leaf extract of Pseudocedrela kotschyi. J App Pharm Sci, 2016; 6 (03): 107-110. 